J. Product. \& Dev., 24(2): $341-352$ (2019)

\title{
EFFECT OF SPRAYING EQUIPMENT TYPE ON THE EFFECTIVENESS OF SOME INSECTICIDES AGAINST THE DIFFERENT SPECIES OF GRASSHOPPERS UNDER THE FIELD CONDITION
}

\author{
S. S. Abdel-Ghaffar *; Romeh, A.A.**; El-Sharkawy, H.M.**andAbdel- \\ Fattah, T. A. **** \\ * General Administration of Locusts and Agricultural Aviation Ministry of \\ Agriculture, Dokki, Giza Egypt \\ ** Plant Production Department, Faculty of Technology and Development, \\ Zagazig University, Egypt \\ ***Locust and Grasshoppers Research department, Plant Protection Research \\ Institute, A.R.C., Giza, Egypt
}

\section{ABSTRACT}

Grasshoppers are major pests of agriculture throughout much of the world. Chemical control of grasshoppers played a major role in suppression the damage of these pests. Efficacy of some chemical insecticide formulations was studied against 3rd, 4th and 5th nymphal instars and adults of different species of grasshoppers at the region of Gharb El-Mawhoop, New-Valley governorate, Egypt by using micron ULVA sprayer (ULVA+), Knapsack mist blower fifed with micron air rotary cage (AU8000) and Knapsack mist blower (ordinary back motor). Mortality percentages were calculated after 24, 48 and $72 \mathrm{hrs}$ post- treatment for chemical insecticide treatments.

The results indicated that Knapsack mist blower fitted with micron air rotary cage (AU8000) was more effective against 3rd, 4th and 5th nymphal instars and adults of grasshoppers than micron ULVA sprayer (ULVA+) for all treatments. Cypermethrin, fipronil, and fenitrothion recorded more toxicity after 24,48 and 72 hrs by using full doses more than half doses or quarter doses against nymphal instars and adult stages of grasshoppers, despite of that, the application with half dose give mortality percentages approximately as the full dose, which resulted in reduction of the amount of pesticides and declined pollution of environmental ecosystems, so it is preferable to use the half dose for saving money and low pollution.

Conclusively, from this results it could be concluded that the pesticides used have been descendingly arranged according to the efficiency as cypermethrin > fipronil > fenitrothion at all the treatments 
by using spraying method with ordinary motor back.

Keywords: spraying equipment, grasshoppers, chemical control

\section{INTRODUCTION:}

Grasshoppers (Orthoptera: Acrididae) are considered one group of a serious agricultural pests that cause considerable damage to different crops and pasture grasses in Africa and Western Asia particularly during outbreaks (Showler, 1993). The desert locust, Schistocerca gregaria (Forsk.) and several species of grasshoppers such as; Euprepocnemis plorans plorans, Hetracerus annulosa, Acrotylus insubricus, Chrotogonus homalodemis, Acrididella nasuta, catantops axillaris and Aiolopus strepens were found to attack agricultural crops in Egypt and many parts of the world (Maya et al., 2005; Capinera et al., 2004; Avanesyan and Culley, 2015). The desert locust and grasshoppers have a very high reproductive rate and able to respond to unfavorable climatic conditions with a rapid population increase (Bateman et al., 1993). In Egypt the most economic species that caused a serious damage is the berseem grasshoppers, E. plorans plorans and Hetracerus annulosa. These species cause 95\% damage to crops of the El-Farafra Oasis at the New Valley, El-Baharia Oasis and Nile Delta during 2008 and 2009 seasons (Abdel-Fattah, 2005). Abdel-Fattah, et al., (2012) found that berseem grasshopper was the most dominant insect pest at Atmida, Met-Ghamr, El-Dakahlia Governorate the principal strategies for locust and grasshopper control have been designed to reduce size of the total population of insects.

It is worth mentioning that, the chemical control of locust and grasshoppers played a major role in suppression the damage of these pests. To achieve accurate distribution on the target area requires the production of spray droplets of an appropriate size, neither too large which fall out onto the ground nor too small which drift off target (Rachadi 2010). Research with the exhaust nozzle sprayer (ENS) demonstrated that efficacy was improved by reducing the volume applied as droplet size decreased and droplet number increased. Consequently, utilizing adequate spray with a small droplet size is much more efficacious than applying a higher volume of liquid (Rachadi 2010). The ULV spray can be used for control of migrant pests (e.g. locust and grasshoppers) with ULV formulations. The 
sprayer produces relatively small spray droplets which are distributed and deposited by wind and gravity, allowing several rows/meter to be treated during each spray passes. Development of centrifugal energy nozzles has led to the concept of controlling droplet application (CDA), so that sprays are applied in a narrow range of droplet sizes, selected according to the target at which the pesticide is aimed (Parnell et al., 1999). ULV applications with water-based formulations are not suitable because locust and grasshopper control most often take place under hot and dry conditions and droplets under 200 microns are susceptible to quick evaporation. ULV formulations almost always are oil-based and applied without mixing (ready to use). When it is required to decrease dose rate or to raise the volume of application, it is possible to mix the original formulation with oil (Rachadi 2010).

Therefore, the present study aimed to investigate the effect of micron UIva+ hand held spinning disc sprayer (UIva+) and knapsack mist plower fitted with micron AU8000 rotatory cage atomizer on the toxicity of some insecticides against the grasshoppers under the field conditions in the New valley in the region of Gharb El-Mawhoop, Egypt.

\section{MATERIALS AND METHODS:}

\section{The insecticides used:}

Chloropyrifos (Chloropyrifos, 45\% U.L.V) at the rate of 1 Liter/ha, cypermethrin (Cypermethrin, 10\% EC) at the rate of 1 Liter/ha, fipronil (Koach, SC $20 \%$ ) at the rate of $200 \mathrm{ml} /$ feddan and fenitrothion (Somethion, $50 \%$ EC) at the rate of 1 Liter/feddan. The half and quarter of applied dose were also, tested.

\section{Application equipment's:}

The experimental plane involved three sprayer equipment's as follow: 1Micron ULVA+ spinning disk sprayer using the blue nozzle at the rate of 28 ml sunflower oil / min. 2- Knapsack mist blower fitted with micron air AU8000 rotary cage atomizer and using the nozzle number 2 at the rate of $125 \mathrm{ml}$ sunflower oil/min 3- Knapsack mist blower (Ordinary back motor) using the nozzle number 2 at the rate of $400 \mathrm{ml}$ water / min. All applications were made at a walking speed of $40 \mathrm{~m} / \mathrm{min}$ with the sprayer held $0.3-0.5 \mathrm{~m}$ above the crop. The swath width for micron ULVA+, Knapsack mist blower fitted with micron air AU8000 and Knapsack mistblower were 3m, 10m and $5 \mathrm{~m}$, respectively according to wind velocity. By the time of application, the temperature reached $33 \pm 2^{\circ} \mathrm{C}$ and the humidity arrived to $52 \% \pm 2 \%$. 


\section{Experimental design:}

Field application of the tested insecticides was conducted in experimental plots of grasses and pushes heavily infested with $3^{\text {rd }}, 4^{\text {th }}$ and $5^{\text {th }}$ nymphal instar and adults of the grasshoppers, Euprepocnemis plorans plorans Charp, Hetracerus annilosa Ramb, Aiolopus strepens Later, Calliptamus spp, Acrotylus insubricus Scop and Chrotogonus homalodemis (more than 25 nymphs $/ \mathrm{m}^{2}$ ). Also, experimental plots of clover heavily infested with 3rd, 4th instar nymphs and adults of Euprepocnemis plorans plorans and Hetracerus annilosa more than 25 insects $\left./ \mathrm{m}^{2}\right)$. Each plot was about $1050 \mathrm{~m}^{2}(35 \times 30)$. The plots were isolated by wide area $(10 \times 25 \mathrm{~m})$, to prevent immigration of treated nymphs to the control plots, and to avoid the drift of spray.

The untreated check plot was sprayed with water only in the case of E.C. or S.C. but in the case of U.L.V. formulations the untreated check plot was sprayed with sunflower oil as a carrier.

Each treatment was represented by five replicate cages $0.5 \mathrm{~m}^{2}$. The insects were collected randomly from the same treatment after application directly by using sweep-net and placed in the cages. The cages were left and kept on the area of treatment under the trees. Fifty insect were kept per cage and fed with treated plants. Mortality counts were recorded after 24, 48 and 72 hrs post treatment. The insects were considered dead when they were unable to right themselves when turned upside down (Mac Cuaig and Yeates Maureen 1961). Daily, cages subjected to the routine work included removing the previous uneaten food, faces and dead nymphs and counting the living insects before introducing the fresh food.

\section{Statistical Analysis:}

Mortality percentages were calculated after 24, 48, and $72 \mathrm{hrs}$. post treatment. Pesticides efficacy in the present study was expressed as \% of mortality. Average mortality percentages were subjected to log transformation according to Sokal and Rohlf 1969 as follow: then subjected to analysis of variance using CoStat software version 6.4 from cohort software.

\section{RESULTS AND DISUSSION:}

The results of ecological survey showed that ocurance of different species of grasshoppers including Euprepocnemis plorans plorans Charp, Hetracerus annilosa Ramb, Aiolopus strepens Later, Calliptamus spp., Acrotylus insubricus Scop and Chrotogonus homalodemis. These sites were characterized by high population density of grasshoppers (more than 25 insect $/ \mathrm{m}^{2}$ ). The studied nymphs were $3^{\text {th }}, 4^{\text {th }}$ and $5^{\text {th }}$ instars and adults. The 
grasshopper, $H$. annilosa considered one of the most harmful pests to different cultivated crops in Egypt. Its economic importance comes from attacking many vegetables cultivated areas even trees, feeding on it and causing great losses in quantity and quality of the attacked crops (Sharaby et al. 2013), Agwu et al., (2016) showed that Zonocerus variegatus (L.) (Orthoptera: Pyrgomorphidae) is the main grasshopper pest of food crops including cassava, citrus, cocoa, banana, coffee, cowpea and yams in the humid lowland forest and savannas of West and Central Africa. Andersen et al. (2000), who also reported that Acrididae grasshoppers were the largest group followed by Tettigoniidae and Pyrgomorphidae in the Kakadu National Park, Australia. Kandibane et al. (2004) and Maya et al. (2005) have added information on grasshopper fauna of different regions of India.

Data in Table (1) show the effect of Chloropyrifos insecticide as ULV against different nymphal instars and adults of the grasshoppers by using two spraying equipment's after 24,48 and $72 \mathrm{hrs}$ post treatment during summer seasons of 2016 and 2017. The results showed that there is no mortality in the check (control) by vegetable oil, also there were significant difference between micron air (AU8000) and ULVA+ spraying, where micron air (AU8000) showed better results than (ULVA+) using full, half and quarter of application dose in the first and second seasons. There were no significant differaces between $1^{\text {st }}$ and $2^{\text {nd }}$ seasons at all tested doses. The mortality percentages of Chlorpyrifos by using ULVA+ at full dose were 92.67 and $93.87 \%$ at the first season and second season while reached 95.07 and $94.67 \%$ by using (AU8000), respectively

While in case of half dose the mortality was 82.70 and $83.07 \%$ in the $1^{\text {st }}$ and $2^{\text {nd }}$ seasons using $\mathrm{ULVA}^{+}$and 89.07 and $90.13 \%$ using AU 8000, respectively. Same mortalities of quarter dose were 75.60 and $76.80 \%$ in the $1^{\text {st }}$ and $2^{\text {nd }}$ seasons using $\mathrm{ULVA}^{+}$and 81.20 and 83.20\% using AU 8000, respectively. In conclusion, use of vegetable oil (sunflower oil) as a carrier was more effective to control of the grasshoppers by using two spraying equipment's. These results are in agreement with Prior et al. (1995), AbdelFattah (2005), Ali (2009), Abdel-Fattah et al. (2012), Abdel-Fattah and Abdel-Lattef (2013) and Hosny et al. (2009). Also, the spraying method by using Knapsack mist blower fitted with micronair (AU8000) was more effective than using ULVA+ sprayer for all treatments. Number of droplets $/ \mathrm{cm}^{2}$ increased or decreased according to different nozzles as to flow rate and different carrier (Water, diesel oil and vegetable oil). Similarly, the effectiveness of the insecticides against the nymphal instars

Table (1): Comparison between ULVA+ and knapsack mist blower fitted 
with micron air (AU8000) on the efficiency of chlorpyrifos against different species of grasshoppers in the field at New Valley, Gharb El-Mawhoop district.

\begin{tabular}{|c|c|c|c|c|c|c|c|c|}
\hline \multirow{3}{*}{$\begin{array}{c}\text { Seasons } \\
\begin{array}{r}\text { Periods } \\
\text { (hours) }\end{array} \\
\text { Spraying } \\
\text { equipment }\end{array}$} & \multirow{2}{*}{\multicolumn{4}{|c|}{$\begin{array}{c}\text { First season (2016) } \\
\text { Post-treatment periods }\end{array}$}} & \multirow{2}{*}{\multicolumn{4}{|c|}{$\begin{array}{c}\text { Second season (2017) } \\
\text { Post-treatment periods }\end{array}$}} \\
\hline & & & & & & & & \\
\hline & $24 \mathrm{~h}$ & $48 \mathrm{~h}$ & $72 \mathrm{~h}$ & Average $^{*}$ & $24 \mathrm{~h}$ & $48 \mathrm{~h}$ & $72 \mathrm{~h}$ & Average $^{*}$ \\
\hline \multicolumn{9}{|c|}{ Full dose } \\
\hline Control & $0 \%$ & $0 \%$ & $0 \%$ & $0 \%$ & $0 \%$ & $0 \%$ & $0 \%$ & $0 \%$ \\
\hline $\begin{array}{l}\text { Micron air } \\
\text { AU } 8000\end{array}$ & $89.60 \%$ & $96.00 \%$ & $99.60 \%$ & $95.07 \%$ a & $89.20 \%$ & $95.60 \%$ & $99.20 \%$ & $94.67 \% \mathrm{a}$ \\
\hline $\begin{array}{c}\text { Ulva+ } \\
\text { Knapsack } \\
\text { mist blower }\end{array}$ & $86.00 \%$ & $94.80 \%$ & $97.20 \%$ & $92.67 \%$ b & $87.60 \%$ & $95.20 \%$ & $98.80 \%$ & $93.87 \% b$ \\
\hline \multicolumn{9}{|c|}{ Half dose } \\
\hline Control & $0 \%$ & $0 \%$ & $0 \%$ & $0 \%$ & $0 \%$ & $0 \%$ & $0 \%$ & $0 \%$ \\
\hline $\begin{array}{c}\text { Micron air } \\
\text { AU } 8000\end{array}$ & $82.00 \%$ & $90.80 \%$ & $94.40 \%$ & $89.07 \%$ a & $83.20 \%$ & $91.60 \%$ & $95.60 \%$ & $90.13 \% \mathrm{a}$ \\
\hline $\begin{array}{c}\text { Ulva+ } \\
\text { Knapsack } \\
\text { mist blower }\end{array}$ & $73.60 \%$ & $83.60 \%$ & $89.00 \%$ & $82.70 \%$ b & $74.80 \%$ & $84.00 \%$ & $90.40 \%$ & 83.07\%b \\
\hline \multicolumn{9}{|c|}{ Quarter dose } \\
\hline Control & $0 \%$ & $0 \%$ & $0 \%$ & $0 \%$ & $0 \%$ & $0 \%$ & $0 \%$ & $0 \%$ \\
\hline $\begin{array}{c}\text { Micron air } \\
\text { AU } 8000\end{array}$ & $76.00 \%$ & $81.20 \%$ & $86.40 \%$ & $81.20 \%$ a & $78.80 \%$ & $83.60 \%$ & $87.20 \%$ & $83.20 \% \mathrm{a}$ \\
\hline $\begin{array}{c}\text { Ulva+ } \\
\text { Knapsack } \\
\text { mist blower }\end{array}$ & $68.00 \%$ & $75.60 \%$ & $83.20 \%$ & $75.60 \% \mathrm{~b}$ & $69.20 \%$ & $76.80 \%$ & $84.40 \%$ & $76.80 \% \mathrm{~b}$ \\
\hline
\end{tabular}

* Percentages with same letter did not differ significantly

$\left(2^{\text {th }}, 3^{\text {th }}, 4^{\text {th }}\right.$ and $\left.5^{\text {th }}\right)$ of the desert locust was differed according to the type of nozzles and the type of carrier, water or oil (Abdel-Fatah and Ammar 2005). The use of low volume spray could be recommended since the use of such sprayer reduces the time, save effort, money and losses of spray solution. In addition, the low volume spraying gave a better coverage of the spray solution on plant leaves. Spraying method by using Knapsack mist blower fitted with micronair (AU8000) indicated that it is specific for controlling Acrididae pests.

The effect of cypermethrin, fipronil, and fenitrothion under the field conditions against 2 rd, 3 rd 4 th, 5 th nymphal instars and adult stages of grasshoppers after 24, 48, and 72 hrs post treatment by using the Knapsack mist blower during summer seasons of 2016 and 2017 are shown in Table 2.

Data in Table 2 obtained during the present investigation revealed that 
the mortality percentages of nymphal instars and adults of the grasshoppers after 24, 48 and 72 hrs through the two seasons by Cypermethrin were always higher than those caused by Fipronil or Fenitrothion. The toxicity was arranged in descending as follows cypermethrin $>$ fipronil $>$ fenitrothion after 24,48 , and $72 \mathrm{hrs}$ post treatment at both the two seasons and at the three applied doses. At the first season, the average mortality percentages were 93.73, 90.40 and $82.80 \%$ for cypermethrin, fipronil, and fenitrothion at the full dose, 87.60, 84.27 and 76.27\% at the half dose and 82.67, 80.27 and $71.07 \%$ at the quarter dose, respectively (Table 2). At the second season, the average mortality percentages reached $94.80,91.47$ and $84.00 \%$ for cypermethrin, fipronil, and fenitrothion at the full dose; 89.00, 86.27 and $78.27 \%$ at the half dose and $84.13,81.20$ and $72.00 \%$ at the quarter dose, respectively (Table 2). On the other hand results showed that there is no mortality in untreated control after $24 \mathrm{hrs}, 48 \mathrm{hrs}$ and $72 \mathrm{hrs}$. The better control efficacy of cypermethrin against nymphal instars and adults of the grasshoppers than fipronil, and fenitrothion, may be due to the higher Octanol/water partition coefficient (Log $\mathrm{K}$ ow $=6.54)$ for Cypermethrin than Vipronil (Log $\mathrm{K}$ ow $=4.01)$ and Fenitrothion ( $\log \mathrm{K}$ ow $=3.30)$ that increased lipophilicity, hence increased deposition of the insecticide on the body surface of the inset. Hinks et al., (1989) showed that Cypermethrin is a lipophilic, strongly hydrophobic molecule whose distribution within the insect is likely to be influenced substantially by the carrying capacity and rate of circulation of the haemolymph and the rate at which it will partition into the internal organs.

Most modern control operations for locusts and grasshoppers rely on safer organophosphates such as Fenitrothion, carbamates such as bendiocarb, pyrethroids such as dletamethrin and lambdacyhalothrin, fipronil, and insect growth regulators such as dimilin and triflumeron (FAO, 1998). Behavioral changes of grasshopper Zonocerusvariegatus treated with different concentrations of cypermethrin was observed. These changes included hyperactivity, muscle spasm, fatigue, opening of ovipositor, numbness, to sudden death as the concentrations increased (Agwu et al., 2016).

It is worth mentioning that cypermethrin, fipronil, and fenitrothion recorded more toxicity after 24,48 and 72 hrs by using full doses more than half doses or quarter doses against nymphal instars and adults of the grasshoppers (Table 2), despite of that, the application of quarter dose or half dose preferred instead of the full dose, science both doses caused

Table (2): Mortality percentage of grasshoppers as influenced by the tested insecticides using Knapsack mist blower (Ordinary back motor) in the field at New Valley, Gharb El-Mawhoop district. 


\begin{tabular}{|c|c|c|c|c|c|c|c|c|}
\hline Seasons & \multicolumn{4}{|c|}{ First season 2016} & \multicolumn{4}{|c|}{ Second season 2017} \\
\hline \multirow{2}{*}{$\begin{array}{l}\text { Periods } \\
\text { hours } \\
\text { Spraying } \\
\text { equipment }\end{array}$} & \multicolumn{4}{|c|}{ Post-treatment periods } & \multicolumn{4}{|c|}{ Post-treatment periods } \\
\hline & $24 \mathrm{~h}$ & $48 \mathrm{~h}$ & $72 \mathrm{~h}$ & Average & $24 \mathrm{~h}$ & $48 \mathrm{~h}$ & $72 \mathrm{~h}$ & Average \\
\hline \multicolumn{9}{|c|}{ Full dose } \\
\hline Control & $0 \%$ & $0 \%$ & $0 \%$ & $0 \%$ & $0 \%$ & $0 \%$ & $0 \%$ & $0 \%$ \\
\hline Cypermethrin & $\begin{array}{c}87.60 \\
\%\end{array}$ & $\begin{array}{c}94.80 \\
\%\end{array}$ & $\begin{array}{c}98.80 \\
\%\end{array}$ & $\begin{array}{c}93.73 \% \\
\mathrm{a}\end{array}$ & $\begin{array}{c}89.60 \\
\%\end{array}$ & $\begin{array}{c}95.60 \\
\%\end{array}$ & $\begin{array}{c}99.20 \\
\%\end{array}$ & $\begin{array}{c}94.80 \% \\
a\end{array}$ \\
\hline Fipronil & $\begin{array}{c}81.20 \\
\%\end{array}$ & $\begin{array}{c}93.20 \\
\%\end{array}$ & $\begin{array}{c}96.80 \\
\%\end{array}$ & $\begin{array}{c}90.40 \% \\
a\end{array}$ & $\begin{array}{c}82.00 \\
\%\end{array}$ & $\begin{array}{c}94.80 \\
\%\end{array}$ & $\begin{array}{c}97.60 \\
\%\end{array}$ & $\begin{array}{c}91.47 \% \\
a\end{array}$ \\
\hline Fenitrothion & $\begin{array}{c}73.20 \\
\% \\
\end{array}$ & $\begin{array}{c}83.20 \\
\% \\
\end{array}$ & $\begin{array}{c}92.00 \\
\%\end{array}$ & $\begin{array}{c}82.80 \% \\
\text { b } \\
\end{array}$ & $\begin{array}{c}74.00 \\
\% \\
\end{array}$ & $\begin{array}{c}84.80 \\
\%\end{array}$ & $\begin{array}{c}93.20 \\
\% \\
\end{array}$ & $\begin{array}{c}84.00 \% \\
\text { b }\end{array}$ \\
\hline \multicolumn{9}{|c|}{ Half dose } \\
\hline Control & $0 \%$ & $0 \%$ & $0 \%$ & $0 \%$ & $0 \%$ & $0 \%$ & $0 \%$ & $0 \%$ \\
\hline Cypermethrin & $\begin{array}{c}80.40 \\
\%\end{array}$ & $\begin{array}{c}87.20 \\
\%\end{array}$ & $\begin{array}{c}95.20 \\
\%\end{array}$ & $\begin{array}{c}87.60 \% \\
a\end{array}$ & $\begin{array}{c}81.20 \\
\%\end{array}$ & $\begin{array}{c}88.40 \\
\%\end{array}$ & $\begin{array}{c}96.40 \\
\%\end{array}$ & $89 \%$ a \\
\hline Fipronil & $\begin{array}{c}74.00 \\
\%\end{array}$ & $\begin{array}{c}85.60 \\
\%\end{array}$ & $\begin{array}{c}93.20 \\
\%\end{array}$ & $\begin{array}{c}84.27 \% \\
\text { a }\end{array}$ & $\begin{array}{c}75.20 \\
\%\end{array}$ & $\begin{array}{c}89.20 \\
\%\end{array}$ & $\begin{array}{c}94.40 \\
\%\end{array}$ & $\begin{array}{c}86.27 \% \\
\text { a }\end{array}$ \\
\hline Fenitrothion & $\begin{array}{c}65.20 \\
\% \\
\end{array}$ & $\begin{array}{c}77.20 \\
\% \\
\end{array}$ & $\begin{array}{c}86.40 \\
\% \\
\end{array}$ & $\begin{array}{c}76.27 \% \\
\text { b } \\
\end{array}$ & $\begin{array}{c}66.80 \\
\% \\
\end{array}$ & $\begin{array}{c}78.40 \\
\% \\
\end{array}$ & $\begin{array}{c}89.60 \\
\% \\
\end{array}$ & $\begin{array}{c}78.27 \% \\
\text { b }\end{array}$ \\
\hline \multicolumn{9}{|c|}{ Quarter dose } \\
\hline Control & $0 \%$ & $0 \%$ & $0 \%$ & $0 \%$ & $0 \%$ & $0 \%$ & $0 \%$ & $0 \%$ \\
\hline Cypermethrin & $\begin{array}{c}76.00 \\
\%\end{array}$ & $\begin{array}{c}81.20 \\
\%\end{array}$ & $\begin{array}{c}90.80 \\
\%\end{array}$ & $\begin{array}{c}82.67 \% \\
a\end{array}$ & $\begin{array}{c}77.60 \\
\%\end{array}$ & $\begin{array}{c}83.60 \\
\%\end{array}$ & $\begin{array}{c}91.20 \\
\%\end{array}$ & $\begin{array}{c}84.13 \% \\
\text { a }\end{array}$ \\
\hline Fipronil & $\begin{array}{c}70.80 \\
\% \\
\end{array}$ & $\begin{array}{c}80.80 \\
\% \\
\end{array}$ & $\begin{array}{c}89.20 \\
\% \\
\end{array}$ & $\begin{array}{c}80.27 \% \\
\text { a } \\
\end{array}$ & $\begin{array}{c}71.60 \\
\% \\
\end{array}$ & $\begin{array}{c}81.60 \\
\%\end{array}$ & $\begin{array}{c}90.40 \\
\%\end{array}$ & $\begin{array}{c}81.20 \% \\
\text { b }\end{array}$ \\
\hline Fenitrothion & $\begin{array}{c}60.40 \\
\%\end{array}$ & $\begin{array}{c}71.60 \\
\%\end{array}$ & $\begin{array}{c}81.20 \\
\%\end{array}$ & $\begin{array}{c}71.07 \% \\
\text { b }\end{array}$ & $\begin{array}{c}61.60 \\
\%\end{array}$ & $\begin{array}{c}72.40 \\
\%\end{array}$ & $\begin{array}{c}82.00 \\
\%\end{array}$ & $\begin{array}{c}72.00 \% \\
\mathrm{c}\end{array}$ \\
\hline
\end{tabular}

* Percentages with same letter did not differ significantly

significant mortality, reduced the amount of pesticides and declined pollution of environmental ecosystems.

Data in Table. 2 demonstrated that the toxicity of cypermethrin, fipronil, and fenitrothion at the second season more efficiency than the first season. The obtained results are in consistent with Metaweh (2001); Metaweh and Ali (1999); Abdel-Fattah (2005); Abdel-Fattah and Ammar (2005); Mamadou and Sarr (2009) and Jeffrey et al. (2013).

Conclusively, it could be concluded from the results that the pesticides used have been descendingly arranged according to the efficiency as cypermethrin > fipronil > fenitrothion in all the treatments by using spraying 
method with ordinary motor back.

\section{REFERNCES}

Abdel-Fatah, T.A. (2005). The combined effects of the entomopathogenic fungus, Metarhizium anisopliae var. acridum isolate IMI 330189 (Green Muscle) and the sub-lethal doses of some insecticides on the desert locust, Schistocerca gregaria (Forskal) Egypt J. Agric. Res., 83(2):551-561.

Abdel-Fatah, T.A. and A.E. Ammar (2005). Effect of different restrictors on the toxicity of some Insecticides against the desert locust in AboRamad, Eastern desert, Egypt. Egypt J. of Agric. Res., 83 (2): 563572.

Abdel-Fatah, T.A. and G.M. Abdel-Lattef (2013). Comparison between two spraying equipments and two carriers on the efficacy of some pesticides against different species of grasshoppers in the field. Egypt J. of App. Sci., 28(1): 1-9.

Abdel-Fatah, T.A.; G.A. Mohamed and G.M. Abdel-Lattef (2012). Effectiveness of some insecticides against the desert locust and barsem grasshopper in the field. Egypt J. of Appl. Sci., 27(7):89-96.

Agwu, J.E.; G.E. Odo; J.C. Oloto and M. Uwagbae (2016). Effects of Cypermethrin on the Biochemical Profile of the Hemolymph of the African Pest Grasshopper Zonocerusvariegatus (Linn) International Journal of Biomaterials Science and Engineering, 3(2): 15-19.

Ali, Gehan, M. (2009). Increasing the efficacy of Metarhizium anisopliae var. acridum (Metchnikoff) Soroken and Beauveria bassiana (bals.) Vuill. Using certain essential oils against desert locust and grasshoppers. Egypt Journal of Biological Pest Control, 19:67-72.

Andersen, A.N.; L.M. Lowe and D.C.F. Rentz (2000). The grasshopper (Orthoptera: Acridoidea, Eumastacoidea and Tettigonioidea) fauna of Kakadu National Park in the Australian seasonal tropics: biogeography, habitat associations and functional groups. Australian Journal of Zoology, 48(4): 431-442.

Avanesyan, A. and T.M. Culley (2015). Herbivory of native and exotic North-American prairie grasses by nymph Melanoplus grasshoppers. Plant Ecol., 216: 451-464.

Bateman, R.P.; M. Carey; D. Moore and C. Prior (1993). The enhanced infectivity of Metarhizium anisopliae var. acridum oil Fonnulations to desert locust at low humidities. Annals of Applied Biology, 122: 145152. 
Capinera, J.L.; R.D. Scott and T.J. Walker (2004). Field Guide to Grasshoppers, Crickets, and Katydids of the United States; Cornell University Press: Ithaca, NY, USA.

COSTAT (2005). Version 6.4, Copyright(c), CoHort Software, 798 Lighthouse Ave. PMB 320, Monterey, CA, 93940, USA.

FAO (1998). Evaluation of field trial data on the efficacy and selectivity of insecticides on locusts and grasshoppers. Report by the FAO Locust Pesticide Referee Group. Locust Pest. Referee Group Meet., $7^{\text {th }}$, Rome, Food Agric. Org., Rome, Italy. 24 pp.

Hinks C.F., N.D. Westcott; R.A. Reichle and D.T. Spurr (1989). The Absorption of Cypermethrin in the Grasshopper Melanopluss anguinipes (Fab.): Effects of Volatilisation, Temperature, Age, Sex and Parasitisation by Malameba zocustae (King and Taylor). Pestic. Sci., 20, 75-82

Hosny, A.K.H.; E.A. Agamy; G.Z. Taha and M.M. El-Husseini (2009). Effecacy of the fungus, Metarhizium anisopliae var. acridum against some Acrididae insects. Journal of Biological Pest Control, 19 (2): 135-141.

Jeffrey, B.; J. Karla.; D.W. Sean and P. Rick (2013). Evaluation of a new chemistry for rangeland grasshopper control. Nebraska Beef Cattle Reports. 721pp.

Kandibane, M.; S. Raguraman; N. Ganapathy and K. Gunathilagaraj (2004). Orthoptera diversity in irrigated rice ecosystem in Madurai, Tamil Nadu. Zoo's Print Journal 19 (10): 1663-1664.

Mac Cuaig, R.D. and N.D.B. Yeats Maureen (1961). Recent laboratory tests of insecticides against locust. Journal of Science Food and Agriculture, 12: 861-873.

Mamadou, A. and M. Sarr (2009). Impact of tow insecticides used in the control of the desert locust on Psammotermes hybostoma (Desneus) in Niger. African Entomology, 17(2):147-153.

Maya, S.; K.S. Sreepada and M.J. Hegde (2005). Survey of short-horned grasshoppers (Acrididae) from Dakshina Kannada District, Karnataka. Zoos' Print Journal 20 (9): 1977-1979.

Metaweh, H.H. (2001). Some factors affected the toxicity of some insecticides to the desert locust and grasshoppers. Egyptian Journal of Applied Science, 16 (12): 330-340.

Metaweh, H.H. and I.A. Ali (1999). Toxicity and inducing knock down of some insecticides to fifth instar nymphs of the desert locust collected from the desert or reared in the laboratory Egyptian Journal of Applied Science, 14 (3): 276-286. 
Parnell, M.A.; W.J. King; K.A. Jones; U. Ketunuti and D. Wetchakit (1999). A comparison of motorized knapsack mist blower, medium volume application, and spinning disk, very low volume application, of Helicover paarmigera nuclear polyhedrosis virus on cotton in Thailand. Crop Protection 18 (1999): 259-265.

Prior, C.J.; Y.J. Carey; D.M. Abraham and R.P. Bateman (1995). Development of a bioassay method of entomopathogenic fungi virulent to the desert locust, Schistocerca gregaria Forskal. Journal of Applied Entomology, 119(8): 567-573.

Rachadi, T. (2010). Locust control Handbook. CTA - Post bus $380-6700$ AJ Wageningen, the Netherlands.

Sharaby, A.; M.A. Gesraha; S.A. Montasser; Y.A. Mahmoud and S.A. Ibrahim (2013). Combined Effect of Some Bio-Agents on the Grasshopper, Hetracerus littoralis Under Semi-Field Condition. Ecological Balkanica, 5(1):107-117.

Showler, A.T. (1993). Desert locust, Schistocerca gregaria, Forskal (Orthoptera Acrididae) campaign in Tunisia, 1988. Agricultural Systems, 42: 311-325.

Sokal, R.R. and F.J. Rohlf (1969). Biometry, the principles and practice of statistics in biological research. Freeman and company San Francisco, $776 \mathrm{pp}$.

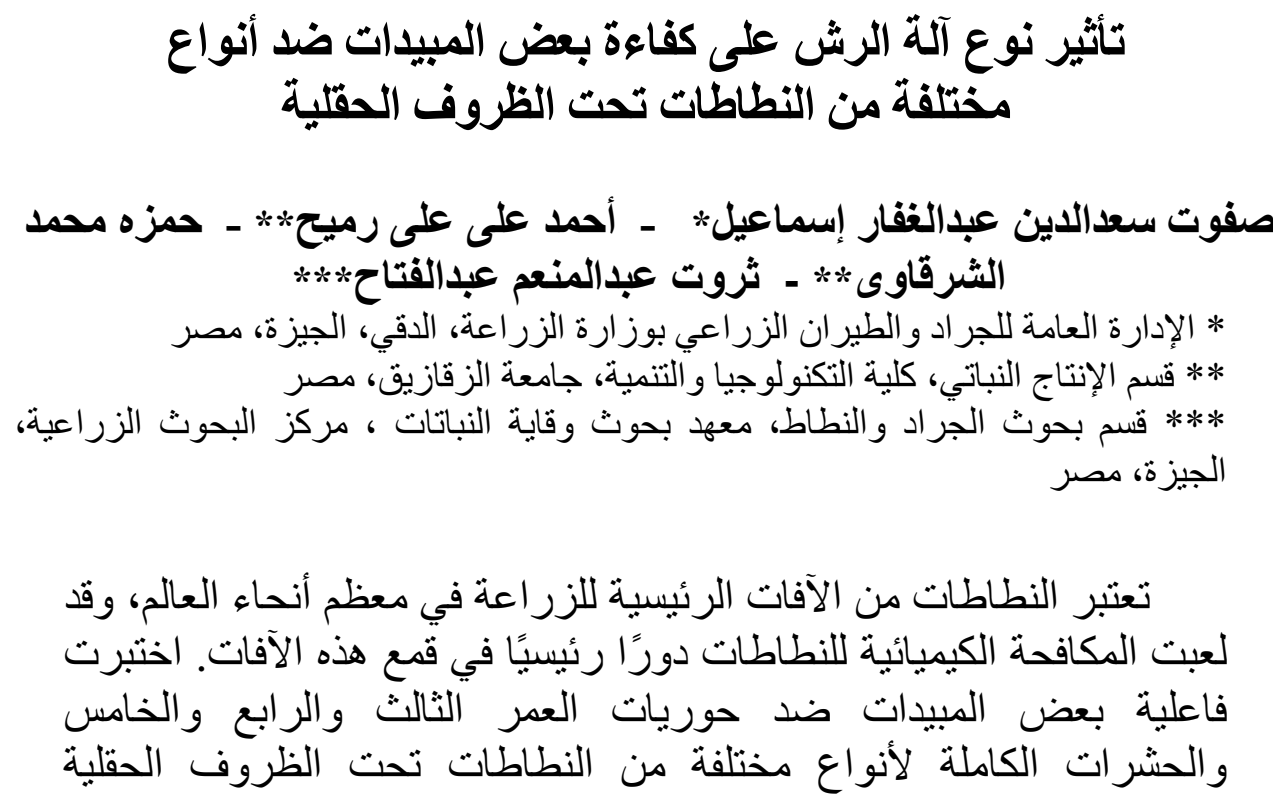




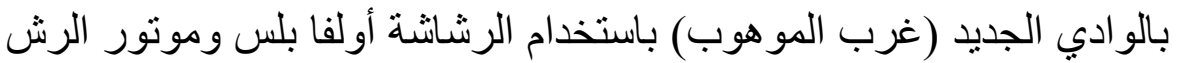

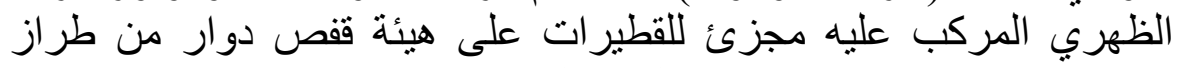
ميكرونيز (AU8000) وموتور الرش العادي.

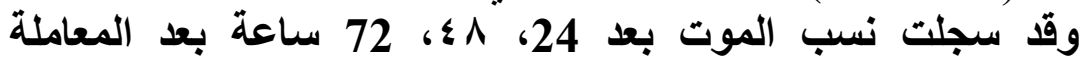

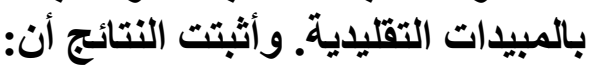

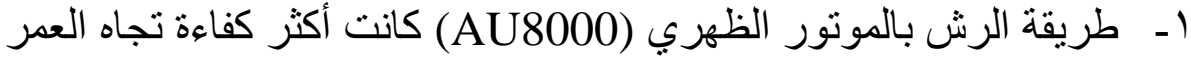

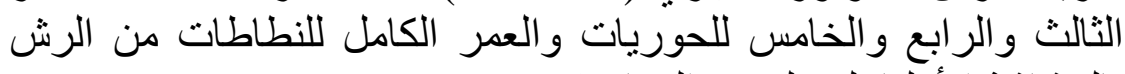
بالرشاشتة الأولفا بلس لجميع المعاملات

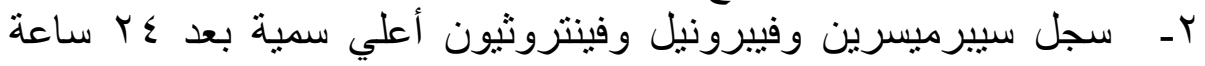

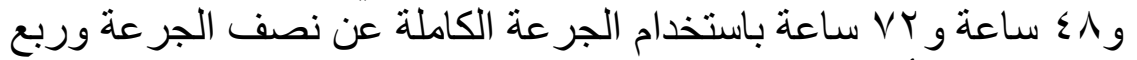

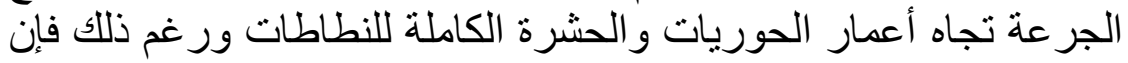

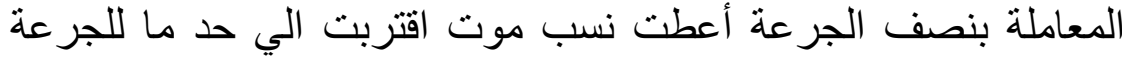

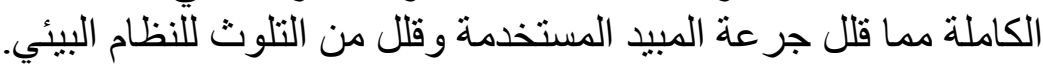

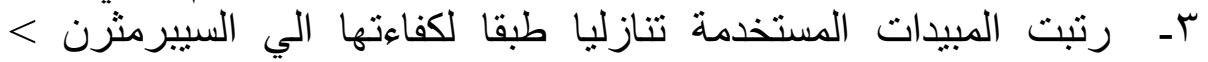

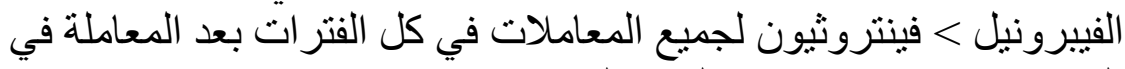
الموسمين باستخدام موتور الرش العين العادي. 